Article - Engineering, Technology and Techniques

\title{
Use of Adsorbent Biochar from Pequi (Caryocar Brasiliense) Husks for the Removal of Commercial Formulation of Glyphosate from Aqueous Media
}

\author{
Lana Lima Borba ${ }^{1}$ \\ https://orcid.org/0000-0002-0950-3232
}

Renata Medici Frayne Cuba ${ }^{2, *}$

https://orcid.org/0000-0002-3455-8198

Francisco Javier Cuba Terán ${ }^{2}$

https://orcid.org/0000-0001-7056-3093

\section{Martha Nascimento Castro ${ }^{1}$}

https://orcid.org/0000-0003-1703-6619

\section{Thiago Augusto Mendes ${ }^{3}$}

https://orcid.org/0000-0001-6910-5722

${ }^{1}$ Pontifical University of Goias, School of Engineering, - Goiania - Goias - Brazil; ${ }^{2}$ Federal University of Goias School of Environmental and Civil Engineering-Goiania - Goias - Brazil; ${ }^{3}$ Federal Institute of Education, Science and Technology of Goias - Aparecida de Goiania - Goias - Brazil;

Received: 2018.08.22; Accepted: 2019.05.19.

* Correspondence: renatafrayne@hotmail.com; Tel.: +55-62-32096541

\section{HIGHLIGHTS}

- Adsorption tests with commercial products are more realistic than with pure products

- Biochar obtained from pequi husks can be used for adsorption of glyphosate

- Low temperature pyrolysis produces biochar for removal of commercial glyphosate

\begin{abstract}
This study evaluated the capacity of adsorbent biochar derived from pequi husks to remove glyphosate (commercial formulation) in aqueous medium under three $\mathrm{pH}$ conditions (5.5, 7.0 and 8.0$)$. This biochar presented a mean yield of $33.1 \% \pm 2.66 \%$ and a high amount of surface particles of small dimensions endowing it with high surface area. The results showed that removal is proportional to $\mathrm{pH}$ increase in the range of 5.5 to 8.0. Adsorption assays performed at $\mathrm{pH} 7$ and 8 fitted better to the Langmuir pseudo-first order kinetics model with fast adsorption in the first 15 to 30 minutes. The results for the acidic $\mathrm{pH}$ range fit none of the adopted models satisfactorily. The results obtained suggest that
\end{abstract}


Borba, L.L.; et al

adsorbent can be used as an efficient and inexpensive alternative for the adsorption of glyphosate present in commercial formulations from aqueous matrices.

Keywords: Agroindustrial waste; Glyphosate commercial formulation; Biochar; Adsorption.

\section{INTRODUCTION}

The extensive use of synthetic herbicides in agriculture for increasing productivity through weed control has intensified on a global scale since 1940 [1]. In this scenario, glyphosate [N-(phosphonomethyl) glycine] has stood out, representing $60 \%$ of the world market [2], due mainly to its selectivity and action against all types of plants [3].

Although most commercial glyphosate formulations are applied to the soil, frequent and widespread use has provided multiple routes for entry of these compounds into the aquatic environment [4] either through leaching and runoff [5] or by accidental spills [6], so that their presence has been detected in surface waters and sediments [7], as well as its toxic effects, in the environment [8] and to human health [9].

According to European guidelines, treatment techniques for reducing the concentration of glyphosate in water are generally expensive, yet necessary for minimizing the risks of residues from its formulations in water for human consumption [6]. Among the techniques employed to remove organic compounds from liquid media is adsorption [10], with commercial activated carbon being one of the absorbent materials most used on an industrial scale [11].

However, despites its versatility and accessibility, its cost is still high due to the use of non-renewable precursor material, such as coal [12]. Thus, biochar has been seen as an alternative adsorbent for the removal or immobilization of inorganic and organic compounds found in soil and water systems [10].

Biochar can be prepared from carbon-rich materials by thermal decomposition under conditions of limited oxygen and temperature $\left(<700^{\circ} \mathrm{C}\right)$ [13]. In this scenario, biomass derived from agroindustrial wastes stand out because it is an inexpensive, abundant, renewable and biodegradable material and because it becomes and environmental problem when inadequately disposed [14].

Pequi (Caryocarbrasiliense) is an oleaginous fruit found in the Central-West, Northeast and North regions of Brazil, as well as in Paraguay and Bolivia [15]. The fruit has an average mass of between 30 to $400 \mathrm{~g}$ with the husk being responsible for about $84 \%$ of the total weight [16], and which is usually discarded [17].

Thus, the objective of this work was to study the use of pequi husks as adsorbent biochar for the removal of glyphosate present in commercial formulation from aqueous media.

\section{MATERIAL AND METHODS}

\section{Materials}

The reagents used were of analytical grade and without prior purification. Stock solution of glyphosate $\left(500 \mathrm{mg} \mathrm{L}^{-1}\right)$ was prepared from the commercial product Roundup®Original $\mathrm{DI}$, consisting of di-ammonium salt of [ $\mathrm{N}$-(phosphomethyl) glycine] $\left(44.5 \% \mathrm{~m} \mathrm{v}^{-1}\right)$, acid equivalent of [ $\mathrm{N}$-(phosphomethyl) glycine] $\left(37.0 \% \mathrm{~m} \mathrm{v}^{-1}\right)$ and other ingredients $\left(75.1 \% \mathrm{~m} \mathrm{v}^{-1}\right)$ not declared by the company. Distilled water was used for the preparation of all solutions.

\section{Preparation of Adsorbent Biochar}

Pequi husks were purchased in a free market in the municipal it of Itapuranga, state of Goiás, Brazil, from September to December 2016. To remove contaminant particles, present on the surface, the husks were immersed in distilled water until the wash water appeared clear, and then exposed to the sun for about one hour for drying. The dried 
material was then subjected to manual cutting into smaller, but not standardized, pieces. The material was then kept in an oven at $105^{\circ} \mathrm{C}$ until constant mass.

The method used to prepare the absorbent biochar consisted of carbonization of the pequi husks in a muffle furnace under an atmosphere of limited oxygen following [18], but with adaptations to temperature and carbonization time, which were $380^{\circ} \mathrm{C}$ and 15 minutes, respectively. The biochar produced was immersed in distilled water to remove the ash, and then dried in an oven at $105^{\circ} \mathrm{C}$ for 24 hours. The dried material was crushed and sieved to obtain particles between $44-74 \mu \mathrm{m}$.

Yield of Adsorbent Biochar

The yield of the adsorbent biochar production process was calculated by means of Equation 1.

$$
\%_{\text {biochar }}=\left(\mathrm{M}_{\mathrm{b}} / \mathrm{M}_{\mathrm{h}}\right) \times 100
$$

Where $M_{b}$ is the mass of biochar obtained after carbonization $(g)$ and $M_{h}$ is the mass of the dry husk $(g)$.

\section{Adsorption Capacity and Isotherms}

Sorption experiments were performed in a batch using micro-controlled Jar-Test equipment (Mod. J-203 MILAN®) with a rotational velocity of $100 \mathrm{rpm}$ [19] and temperature of $22^{\circ} \mathrm{C}$.

The experiments for evaluating the influence of $\mathrm{pH}$ on adsorption were conducted using commercial glyphosate-based solution with concentration of $11.0 \mathrm{mg} \mathrm{L}^{-1}$. For isothermal assays the concentrations were $4.0 \mathrm{mg} \mathrm{L}^{-1}, 6.0 \mathrm{mg} \mathrm{L}^{-1}, 8.0 \mathrm{mg} \mathrm{L}^{-1}, 10.0 \mathrm{mg} \mathrm{L}^{-1}$, $12.0 \mathrm{mg} \mathrm{L}^{-1}$ and $16.0 \mathrm{mg} \mathrm{L}^{-1}$. For both assays, the adsorbent concentration was $1.5 \mathrm{~g} \mathrm{~L}^{-1}$ and the $\mathrm{pH}$ values tested were 5.5, 7.0 and 8.0, obtained and maintained until the end of the assays by the addition of $0.1 \mathrm{M} \mathrm{H}_{2} \mathrm{SO}_{4}$ or $0.1 \mathrm{M} \mathrm{NaOH}$. The contact time of the assays was 300 minutes, based on kinetic adsorption results.

The quantity of glyphosate adsorbed on the biochar (qe) was determined using Equation 2 and the percentage removal $(R)$ using Equation 3 [20].

$$
\begin{aligned}
\mathrm{q}_{\mathrm{e}} & =\frac{\mathrm{V}\left(\mathrm{C}_{0}-\mathrm{C}_{\mathrm{e}}\right)}{\mathrm{m}} \\
\mathrm{R} & =\frac{\left(\mathrm{C}_{0}-\mathrm{C}_{\mathrm{e}}\right)}{\mathrm{C}_{0}} \times 100
\end{aligned}
$$

where $q_{e}$ is the quantity of glyphosate adsorbed per unit mass of adsorbent at equilibrium $\left(\mathrm{mg} \mathrm{g}^{-1}\right), \mathrm{C}_{0}$ and $\mathrm{C}_{\mathrm{e}}$ are the initial and final glyphosate concentrations in solution $\left(\mathrm{mg} \mathrm{L}^{-1}\right), \mathrm{V}$ is the volume of the solution $(\mathrm{L})$ and $\mathrm{m}$ is the mass of the adsorbent $(\mathrm{g})$.

The results obtained with Equation 2 were fitted to Langmuir and Freundlich adsorption models using the software Origin 8.0 (Version 8). The non-linear form of the Langmuir model is presented in Equation 4

$$
\mathrm{q}_{\mathrm{e}}=\frac{\mathrm{q}_{\mathrm{m}} \mathrm{K}_{1} \mathrm{C}_{\mathrm{e}}}{1+\mathrm{K}_{\mathrm{L}} \mathrm{C}_{\mathrm{e}}}
$$

where qe is the quantity of glyphosate adsorbed per unit mass of adsorbent at equilibrium $\left(\mathrm{mg} \mathrm{g}^{-1}\right), \mathrm{q}_{\mathrm{m}}$ is a Langmuir parameter relative to the maximum adsorption capacity in monolayer ( $\left.\mathrm{mg} \mathrm{g}^{-1}\right), \mathrm{K}_{\mathrm{L}}$ is a Langmuir constant relative to the adsorption equilibrium $\left(\mathrm{mg} \mathrm{L}^{-1}\right)$ and $\mathrm{C}_{\mathrm{e}}$ is the equilibrium concentration in solution $\left(\mathrm{mg} \mathrm{L}^{-1}\right)$.

The characteristics of the Langmuir isotherms can be expressed by a separation factor $\mathrm{R}_{\mathrm{L}}$, by means of Equation 5 


$$
\mathrm{R}_{\mathrm{L}}=\frac{1}{1+\mathrm{K}_{\mathrm{L}} \mathrm{C}_{0}}
$$

with values of $R_{L}=0, \quad 0<R_{L}<1, R_{L}=1$ and $R_{L}>1$ suggesting that adsorption is irreversible, favorable, linear and unfavorable, respectively [21].

For the Freundlich model, the nonlinear form in Eq. (6) was also used, as discussed by [22]

$$
\mathrm{q}_{\mathrm{e}}=\mathrm{K}_{\mathrm{F}} \mathrm{C}_{\mathrm{e}}^{\mathrm{n}}
$$

where $\mathrm{K}_{\mathrm{f}}\left(\left(\mathrm{mg} \mathrm{g}^{-1}\right) /\left(\mathrm{mg} \mathrm{L}^{-1}\right) \mathrm{n}\right)$ being the Freundlich constant and $\mathrm{n}$ (dimensionless) a parameter that indicates the magnitude of the adsorption motive force or surface heterogeneity [22].

\section{Adsorption Kinetics}

Kinetic assays were carried out with the same equipment and experimental conditions as in the studies of adsorption, including a glyphosate concentration (commercial formulation) of $11.0 \mathrm{mg} \mathrm{L}^{-1}$. Aliquots of $15 \mathrm{~mL}$ were collected at predetermined time intervals over a period of 180 minutes.

The data obtained were fitted to the pseudo-first order model of Langegren 1898, according to Equation 7, and the pseudo-second order model according to Equation 8, as proposed by Blanchard et al. in 1984 [22].

$$
\mathbf{q}_{\mathrm{t}}=\mathbf{q}_{\mathrm{e}}\left(1-\exp k_{1} \mathbf{t}\right)
$$

$$
q_{t}=\frac{q_{e}^{2} k_{2} t}{1+k_{2} q_{2} t}
$$

where $q_{t}$ is the quantity adsorbed per gram of biochar $\left(\mathrm{mg} \mathrm{g}^{-1}\right)$ at time $t(\mathrm{~min})$ and $k_{1}$ and $k_{2}$ are the adsorption constants of the pseudo-first order $\left(\mathrm{min}^{-1}\right)$ and pseudo-second order $\left(\mathrm{g} \mathrm{mg}^{-1} \mathrm{~min}^{-1}\right)$.

The non-linearized forms of the equations were used because [23] suggest that they produce smaller discrepancies when compared to fitting to linearized equations.

\section{Statistical analyses}

To evaluate the quality of the fits, the values of the correlation coefficients and the chi-square test $\left(x^{2}\right)$ were used as criteria, considering the experimentally observed responses and the values predicted by the model, according to Equation 9 used by [24].

$$
\mathbf{x}^{2}=\sum \frac{\left(\mathbf{q}_{\mathbf{e}}-\mathbf{q}_{\mathbf{e} . \mathbf{m}}\right)^{2}}{\mathbf{q}_{\mathrm{e} . \mathrm{m}}}
$$

where $q_{e}$ is the equilibrium capacity from the experiment data $\left(\mathrm{mg} \mathrm{g}^{-1}\right)$ and $q_{e . m}$ is the equilibrium capacity calculated by the model $\left(\mathrm{mg} \mathrm{g}^{-1}\right)$.

\section{Glyphosate Concentration Analysis}

The analysis of glyphosate concentration was performed according to the method of reaction with ninhydrin and sodium molybdate [25]. Prior to the glyphosate analysis the samples were filtered through $0.45 \mu \mathrm{m}$ cellulose membranes and the $\mathrm{pH}$ adjusted to 7.0 with $0.1 \mathrm{~mol} \mathrm{~L}^{-1} \mathrm{H}_{2} \mathrm{SO}_{4}$ solution or $0.1 \mathrm{~mol} \mathrm{~L}^{-1} \mathrm{NaOH}$ solution.

The calibration curve $\left(R^{2}=0.9919\right)$ of glyphosate was constructed using solutions prepared from the commercial product used in the assays, to avoid interference of other compounds present when compared to the pure product [26]. The working range used was 
$0.1 \mathrm{mg} \mathrm{L}^{-1}$ to $13.0 \mathrm{mg} \mathrm{L}^{-1}$ and the glyphosate readings were made using an FEMTO Cirrus 80SA spectrophotometer. The analyses were don in triplicate.

\section{Characterization of Adsorbent Biochar}

The point of zero charge (PZC) was determined according to the methodologies proposed by [27]. For the assay, $50.0 \mathrm{mg}$ of absorbent biochar was mixed with $20.0 \mathrm{~mL}$ of $0.05 \mathrm{~mol} \mathrm{~L}^{-1} \mathrm{NaCl}$ solution under different conditions of initial $\mathrm{pH}\left(\mathrm{pH}_{0}\right)$, adjusted from 2.0 to 10.0 by the addition of $0.1 \mathrm{~mol} \mathrm{~L}^{-1}$ of $\mathrm{HCl}$ or $\mathrm{NaOH}$ solution. The flasks were sealed with plastic film and stirred for 24 hours on a TECNAL TE-141 orbital shaker at $90 \mathrm{rpm}$ at room temperature $\left(22^{\circ} \mathrm{C} \pm 2^{\circ} \mathrm{C}\right)$. After stirring, the solutions were filtered using $45-\mu \mathrm{m}$ filter paper and the final $\mathrm{pH}\left(\mathrm{pH}_{\mathrm{f}}\right)$ of the solutions measured. The PZC was obtained by plotting supernatant $\mathrm{pH}_{0}-\mathrm{pH}_{\mathrm{f}}$ verses the initial solution $\left(\mathrm{pH}_{0}\right)$ [22].

The surface morphology of the pequi husk samples dried at $105^{\circ} \mathrm{C}$ and the absorbent biochar samples were visualized using a JEOL, JSM - 6610 scanning electron microscope (SEM) equipped with EDS, Thermo scientific NSS Spectral Imaging. The material was covered in gold and the resolution of the images was from 100x to 5000x. Both samples used were those retained in the 325-mesh sieve.

The functional groups on the surface of the biochar (before and after the adsorption assay performed at $\mathrm{pH}=8.0$ ) were identified using a Perkin Elmer Spectrum 400 model infrared spectrophotometer with Fourier transformation. The spectra were recorded from 400 to $4000 \mathrm{~cm}^{-1}$ with 64 scans per spectrum [28]. The baseline data were adjusted and normalized by Perkin Elmer Spectrum software version 6.3.4. Quantification of acidic and basic functional groups was done by means of the Boehm technique, according to the procedure described by [29].

\section{RESULTS}

The steps for raw material processing and adsorbent biochar production can be seen in Figure 1.

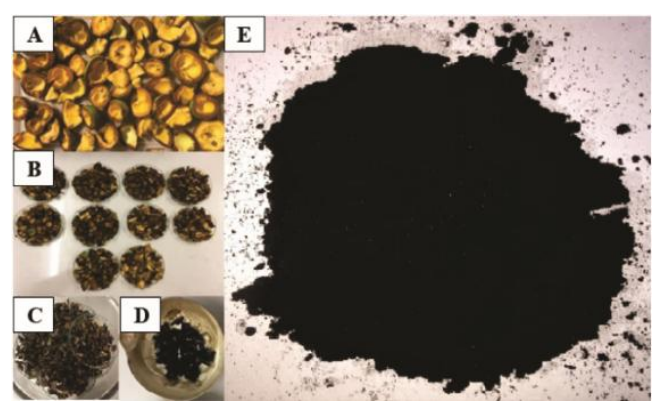

Figure 1. Stages of adsorbent production. A) Pequi husk in natura; B) unstandarized fragments of husks; C) husks after drying at $105^{\circ} \mathrm{C}$, to constant mass; D) adsorbent char E) adsorbent char in the form of particles sizes between 44 and $74 \mu \mathrm{m}$.

\section{Adsorbent Biochar Yield}

The method used to produce the adsorbent biochar had an average yield of $33.1 \% \pm 2.66 \%$. [18] obtained a maximum yield of $7 \%$ for the same product, but these authors used a higher temperature and longer time for pyrolysis $\left(400^{\circ} \mathrm{C}\right.$ and 20 minutes). 
The relationship between biochar yield and preparation temperature is inversely proportional [30] with the proportionality depending on the type of raw material used [31]. This is because pyrolysis carried out at low temperatures results in less loss of $\mathrm{CO}, \mathrm{H}_{2}$, and $\mathrm{CH}_{4}$ of volatile constituents [32], the condensates of which are incorporated by the biochar during the cooling process [33].

\section{Effect of pH on Glyphosate Adsorption}

Solution $\mathrm{pH}$ is one of the most important parameters influencing the adsorption process since it can affect both the adsorbent surface charge [34], and dissociation of the glyphosate species [12]. The adsorption tests at pH 5.5, 7.0 and 8.0 showed an increase in glyphosate removal with increasing $\mathrm{pH}$ of the solution, with values of $\mathrm{q}_{\mathrm{e}}\left(\mathrm{mg} \mathrm{g}^{-1}\right)$ equal to $1.05 \pm 0.22,2.59 \pm 0.42$ and $4.04 \pm 0.34$, respectively, corresponding to the removal of, $35.01 \% \pm 1.5 \%, 35.27 \% \pm 3.06$ and $49.89 \% \pm 7.1 \%$.

Although other authors have verified that the adsorption of glyphosate tends to decrease with increasing $\mathrm{pH}$ of the medium [10,12,35] obtained behavior similar to the present study in the interval of $\mathrm{pH}$ between 3.0 and 6.5 with maximum adsorption between $5.5-6.5$, followed by a sharp decrease with $\mathrm{pH}=8.0$ when using biochar obtained from wood waste of the species Gliricidia sepium.

This behavior can be explained by analyzing, together, the point of zero charge (Figure 2 ), the surface functional groups of the biochar (Table 1) and the ionized glyphosate species as a function of $\mathrm{pH}$ (Table 2).

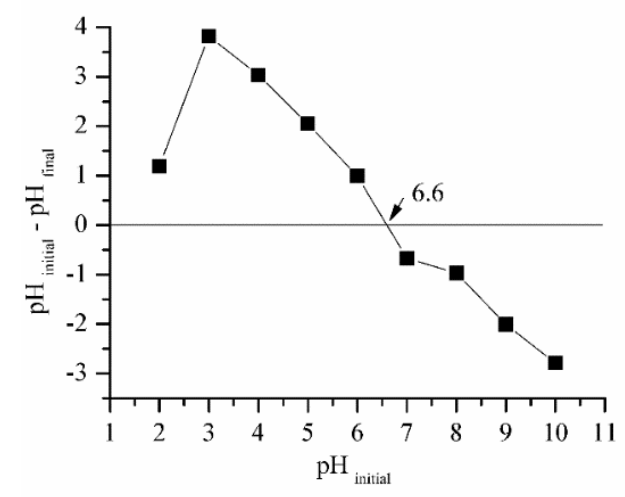

Figure 2. Point Zero Charge $\left(\mathrm{pH}_{\mathrm{pzc}}\right)$ for adsorbent biochar

The point of zero charge $\left(\mathrm{pH}_{\mathrm{pzc}}\right)$ is defined as the $\mathrm{pH}$ and conditions of the medium in which the surface charge density of the adsorbent is zero [22]. Therefore, when the $\mathrm{pH}$ of the solution is lower than $\mathrm{pH}_{\mathrm{pzc}}$, the adsorbent surface has a predominantly positive charge, whereas at $\mathrm{pH}$ values above $\mathrm{pH}_{\mathrm{pzc}}$, the net surface charge is negative $[36,10]$. In the present study, the $\mathrm{pH}_{\mathrm{pzc}}$ was 6.6 , so that at the $\mathrm{pH}$ of 7.0 and 8.0, which had the highest values for adsorption capacity, there is negative surface charge density.

The results of the quantitative analysis of the acid functional groups of the adsorbent surface are presented in Table 1. 
Table 1. Quantitative analysis for functional groups in biochar surface

\begin{tabular}{ccc}
\hline Functional Surface Group & $\mathbf{m E q} \cdot \mathbf{~ g}^{-1}$ & $\%$ \\
\hline$-\mathrm{COOH}$ & 0.94 & 25.61 \\
$-\mathrm{OH}$ & 2.65 & 72.21 \\
$-\mathrm{COOR}$ & 0.08 & 2.18 \\
\hline
\end{tabular}

Since the carboxylic acids have $\mathrm{pK}_{\mathrm{a}}=1.7-4.7$ and the phenolic hydroxyls have $\mathrm{pK}_{\mathrm{a}}=9.5-13.0$ [22], the negative surface charge on the absorbent may be related to the dissociation of the acid oxygen of the carboxylic acid group [37], whereas the phenolic hydroxyls, due to their $\mathrm{pK}_{\mathrm{a}}$ being higher than the study $\mathrm{pH}$ (7.0 and 8.0), are in the non-dissociated form, which allows hydrogen bonding with glyphosate and its dissociated species (Table 2) [36].

Table 2. Dissociation species for glyphosate

\begin{tabular}{|c|c|}
\hline Range of $\mathrm{pH}$ & Dissociated Glyphosate \\
\hline $5.6<\mathrm{pH}<10.6$ & 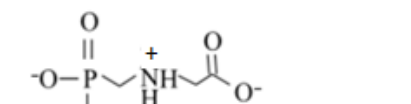 \\
\hline $2.6<\mathrm{pH}<5.6$ & 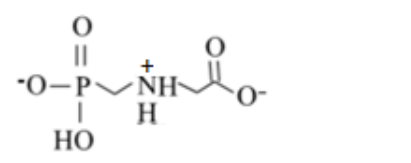 \\
\hline
\end{tabular}

Fonte. Adapted from [35]

The interaction between the functional groups of the biochar and the glyphosate can be evaluated by means of the analysis of the infrared spectra before and after the adsorption of glyphosate (Figure 3). Assignments of peaks were based on previous studies.

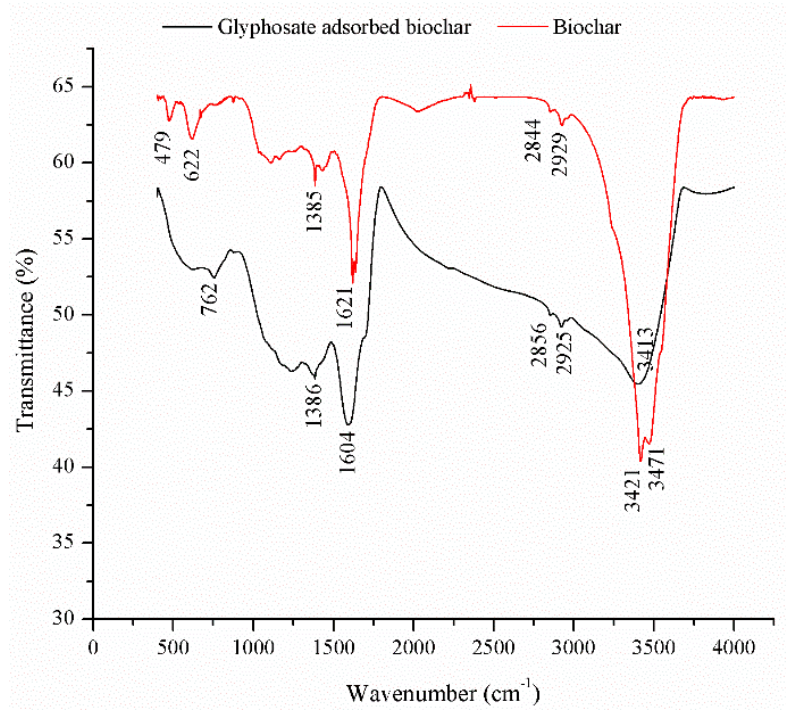

Figure 3. FTIR spectra of biochar and glyphosate adsorbed biochar.

As shown in figure 3 , the peak at $3421 \mathrm{~cm}^{-1}$ can be attributed to the elongation of the phenolic-OH group on the surface of the biobiochar [38], which reinforces the hypothesis of the participation of this group in hydrogen bonds with the glyphosate $[10,35]$ by means of 
the phosphate group, since it was not possible to identify adsorption at $1059 \mathrm{~cm}^{-1}$ and $616 \mathrm{~cm}^{-1}$ or $542 \mathrm{~cm}^{-1}$, which correspond, respectively, to the vibrational modes of asymmetric stretching of the $\mathrm{P}-\mathrm{O}$ bond and vibration of O-P-O both referring to the $\mathrm{PO}_{4}{ }^{-3}$ group [39].

Another suggested mechanism for adsorption of glyphosate is of the cation- $\pi$ type [10] due to the interaction between the amino group of glyphosate, which at $\mathrm{pH} 8.0$ is in its protonated form (see Table 2 ), and the $\pi$-bond electrons via donor-acceptor $\pi^{+}-\pi_{\text {electrons }}$ present on the surface of the biochar [35]. The new N-C bond formed corresponds to the peak observed at $1386 \mathrm{~cm}^{-1}$ [10]. Both mechanisms suggest adsorption of glyphosate in biochar via physical adsorption. However, [23] suggests that the protonated amine group can also attack the ortho- or para- positions of the aromatic ring, giving rise to chemical adsorption mechanisms. The possible adsorption mechanisms proposed by [10] are shown in figure 4.

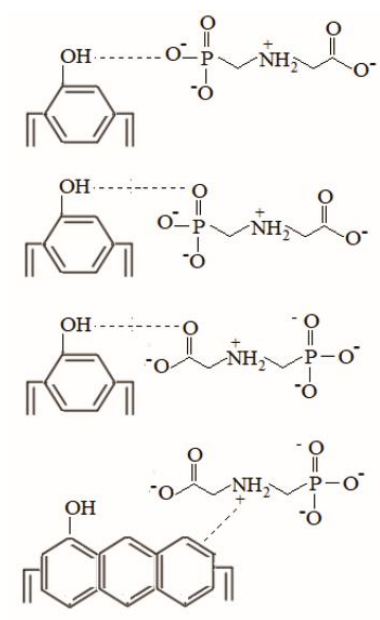

Figure 4. Possible adsorption paths of glyphosate on char surface. Adapted from [10].

The peaks at $2856 \mathrm{~cm}^{-1}$ and $2925 \mathrm{~cm}^{-1}$ were attributed in previous works to the symmetrical or asymmetrical narrowing of the $\mathrm{C}-\mathrm{H}$ bond in methyl $\left(-\mathrm{CH}_{3}\right)$ and methylene $\left(-\mathrm{CH}_{2}\right)$ groups [28, 40]. The absence of peaks around $1730 \mathrm{~cm}^{-1}$, which would correspond to the stretching vibration of the $\mathrm{C}=\mathrm{O}$ bond of nonionic carboxylic groups $(-\mathrm{COOH}$ and- $\mathrm{COOCH}_{3}$ ) along with the presence of the peak at $1604 \mathrm{~cm}^{-1}$, characteristic of asymmetric stretching vibration of their ionized forms [41], reinforces the hypothesis that the surface charge density of the biochar is related to the ionization of carboxylic acids (before adsorption) and the possibility that the $\mathrm{C}=\mathrm{O}$ is used in the adsorption via hydrogen bonding. The peak was more intense after the adsorption process, probably due to the same carboxyl groups belonging to glyphosate. Peaks at wavelengths shorter than $900 \mathrm{~cm}^{-1}\left(479,622\right.$ and $\left.762 \mathrm{~cm}^{-1}\right)$ can be attributed to deformations of $\mathrm{C}-\mathrm{H}$ type bonds related to units of aromatic compounds [10].

Images of the surface of the biochar, as well as the husk of pequi in natura, are presented in figure 5 . 

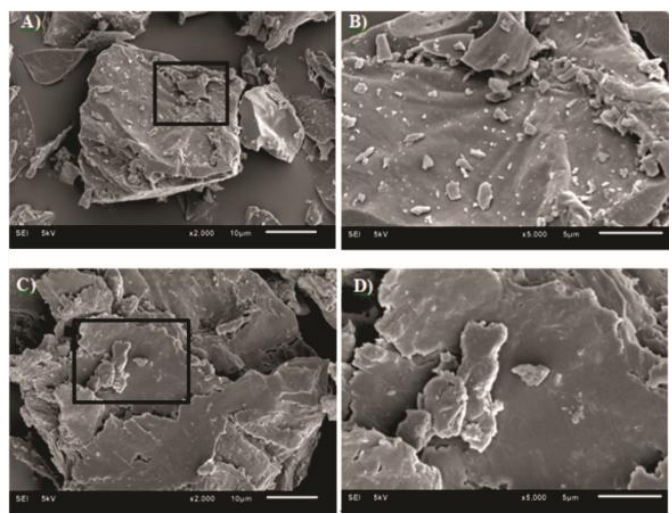

Figure 5. SEM micrographs from the surface of biochar (A, B) and from pequi surface in natura (C and D). Boxes correspond to $5000 x$ magnification images.

Comparison of the surface of the biochar with that of the pequi husk in natura, verifies that the carbonization process added a great quantity of fine particulate material to the surface of the solids, rendering the surface less uniform. The smaller particle size of the absorbent material endows a greater surface specific for adsorption, thereby favoring the process.

\section{Adsorption kinetics}

The results of the adsorption kinetic assays obtained in $\mathrm{pH}=7.0(\mathrm{~A})$ and $\mathrm{pH}=8.0(\mathrm{~B})$, are shown in Figure 6.
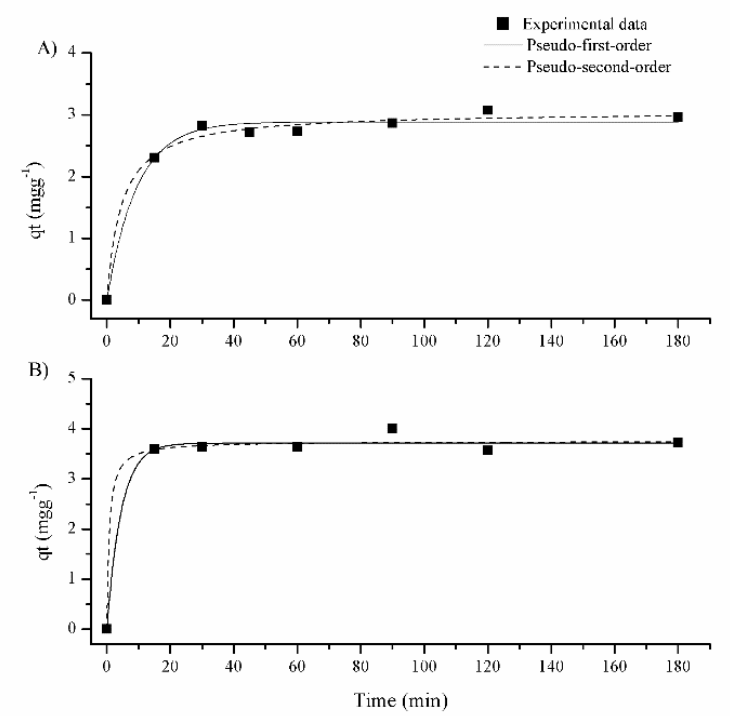

Figure 6. Results of kinetic tests performed in pH $7.0(\mathrm{~A})$ and pH 8.0 (B).

The results presented in Figure 5 demonstrate that glyphosate was rapidly adsorbed. In the first 30 minutes of contact at $\mathrm{pH}=7.0,61.6 \%$ of the removal occurred, while at $\mathrm{pH}=$ 8.0 , approximately $68.6 \%$ was achieved in the first 15 minutes of the assay. These removal times were lower than those reported in the literature. [10] obtained removal on the order of $73 \%$ with 60 minutes of contact, while [35] had the largest part removed in 50 minutes and [3] in about 75 minutes.

Table 3 shows the data for the kinetic parameters obtained from fitting to the pseudo-first order and pseudo-second order models at both $\mathrm{pH}$ levels 
Table 3. Kinetic parameters from glyphosate adsorption on biochar.

\begin{tabular}{ccccc}
\hline Kinetic Parameters & \multicolumn{2}{c}{ Pseudo-first Order } & \multicolumn{2}{c}{ Pseudo-second Order } \\
\hline & pH 7.0 & $\mathbf{p H ~ 8 . 0}$ & $\mathbf{p H ~ 7 . 0}$ & $\mathbf{p H ~ 8 . 0}$ \\
\hline$q_{e . m}\left(\mathrm{mg} \mathrm{g}^{-1}\right)$ & 2.882 & 3.714 & 3.057 & 3.753 \\
$q_{e}\left(\mathrm{mg} \mathrm{g}^{-1}\right)$ & 2.615 & 3.606 & 2.615 & 3.606 \\
$k_{1}\left(\mathrm{~min}^{-1}\right) / k_{2}\left(\mathrm{~g} \mathrm{mg}^{-1} \mathrm{~min}^{-1}\right)$ & 0.10632 & 0.22227 & 0.07145 & 0.36688 \\
$R^{2}$ & 0.98543 & 0.98866 & 0.98944 & 0.98910 \\
$X^{2}$ & 0.01481 & 0.02231 & 0.01074 & 0.02144
\end{tabular}

In order to analyze the quality of the fit of the experimental results to the kinetic models, in addition to the values of $R^{2}$ and $X^{2}$, a comparison was also made between the values of experimental adsorption capacity $\left(q_{\text {eexp }}\right)$ and those obtained from the model $\left(q_{e}\right)[28,42]$. When analyzing the obtained data, it was verified that for the assays performed at $\mathrm{pH} 7.0$, the values of $R^{2}$ and $X^{2}$ are consistent and very close for both models, however, the results suggest that the pseudo-first order model is the more representative of the data obtained since the difference between the values of $q_{\text {eexp }}$ obtained experimentally and those calculated by the model is smaller.

A similar situation, however, was less pronounced in the assays carried out at $\mathrm{pH}=8.0$. In the literature, kinetics data are generally described as pseudo-second order [3, 28, 35]. However, [10] also obtained the pseudo-first order model as the best kinetic fit of its experimental data with a $K_{1}$ value of $0.0318 \mathrm{~min}^{-1}$, well below that obtained by the present study of $0.10632 \mathrm{~min}^{-1}(\mathrm{pH}=7.0)$ and $0.22227 \mathrm{~min}^{-1}(\mathrm{pH}=8.0)$.

The pseudo-first order model indicates that the determining step of the adsorption process is governed by physical mechanisms [43]. The assays conducted at acidic $\mathrm{pH}$ did not fit satisfactorily any kinetic model.

\section{Adsorption isotherms}

Isotherms are used to describe the adsorption process by relating the amount of adsorbed substance per unit mass of adsorbent and the remaining substance in solution [12].

The results of the adsorption of glyphosate on pequi-based biochar at the $\mathrm{pH}$ of 7.0 and 8.0 were fitted to two isotherm models: Langmuir and Freundlich (Figure 7), whose parameters are shown in Table 4. 

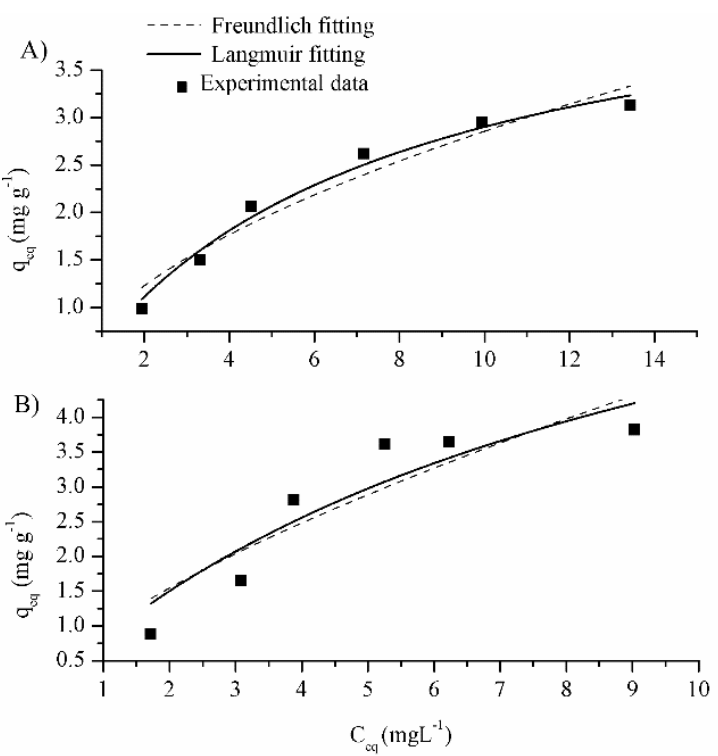

Figure 7. Freundlich and Langmuir isotherm fittings in $\mathrm{pH} 7.0$ (A) and $\mathrm{pH} 8.0$ (B)

To analyze the quality of the fit of the experimental results to the proposed models, values of $\mathrm{R}^{2}$ [23, 35], and $X^{2}$ (Equation 8 ) were used. For the latter, the smaller the value the greater the similarity between the experimental data and the model [24].

Table 4. Isotherm parameters for glyphosate adsorption. All parameters were calculated by non-linear regression.

\begin{tabular}{lcclll}
\hline \multicolumn{3}{c}{ Freundlich } & \multicolumn{2}{c}{ Langmuir } \\
\hline & \multicolumn{2}{c}{ pH } & & \multicolumn{2}{c}{ pH } \\
\hline Parameters & $\mathbf{7 . 0}$ & $\mathbf{8 . 0}$ & Parameters & $\mathbf{7 . 0}$ & \multicolumn{1}{c}{$\mathbf{8 . 0}$} \\
\hline$K_{f}\left(\mathrm{mg} \mathrm{g}^{-1}\right)$ & 0.85460 & 0.96446 & $K_{L}\left(\mathrm{~L} \mathrm{mg}^{-1}\right)$ & 0.14489 & 0.10596 \\
$n$ & 0.52378 & 0.68096 & $q_{m}\left(\mathrm{mg} \mathrm{g}^{-1}\right)$ & 4.8558 & 8.5904 \\
$R^{2}$ & 0.93387 & 0.77747 & $R_{L}$ & 0.4401 & 0.9509 \\
$X^{2}$ & 0.04819 & 0.32892 & $R^{2}$ & 0.9791 & 0.8316 \\
& & & $X^{2}$ & 0.0482 & 0.2489 \\
\hline
\end{tabular}

The high correlation coefficients and the low values of $X^{2}$ (Table 4) suggest that the data obtained can be adequately represented by both the Langmuir and Freundlich models in both $\mathrm{pH}$ conditions tested, with Langmuir being best suited to the results.

Based on Langmuir isotherm principles, adsorption occurs in monolayers on the surface, which contains a finite number of identical adsorption sites [44]. It also assumes that the adsorption energies at the surface of the adsorbent are uniform, that there is no adsorbent transmigration in the surface plane and that there is no interaction among adsorbed molecules [12]. The high degree of similarity between the experimental results obtained with those predicted by the Langmuir model indicates that the observed adsorption is governed by both physical and chemical phenomena [43].

The Freundlich model adopts multilayer adsorption on a heterogeneous surface with different adsorption energies having values of $n<1$ indicating that the adsorption sites are not evenly distributed on the surface of the adsorbent material [10]. 
According to the Langmuir model, the maximum adsorption capacity increased with increasing $\mathrm{pH}$ from $4.85 \mathrm{mg} \mathrm{g}^{-1}(\mathrm{pH}=7.0)$ to $8.59 \mathrm{mg} \mathrm{g}^{-1}(\mathrm{pH}=8.0)$, a behavior also verified by [34], but with higher adsorption values. Although the adsorption capacity of the present study was low compared to other studies, including $48.4 \mathrm{mg} \mathrm{g}^{-1}$ for [12], $44.0 \mathrm{mg} \mathrm{g}^{-1}$ for [35], and $123.03 \mathrm{mg} \mathrm{g}^{-1}$ for [10], these authors used pure glyphosate while the present study used a commercial formulation that has other compounds in its composition such as, for example, surfactants that increase the efficiency of glyphosate but may also produce high adsorption capacities [45]. Even though the values for adsorption capacity were lower than those with the pure product, $R_{L}$ values of 0 - 1 indicate favorable adsorption [42]. For the acid pH value there was no satisfactory fit.

\section{CONCLUSION}

A 15 -min calcination at $380^{\circ} \mathrm{C}$ obtained $33.1 \%$ of adsorbent material. The removal efficiencies for $\mathrm{pH}$ conditions of $5.5,7.0$ and 8.0 were, respectively, $35.01 \%, 35.27 \%$ and $49.89 \%$.

Adsorption occurs primarily in monolayers, is homogeneous, and governed by the Langmuir model.

At $\mathrm{pH}=7.0$ and $\mathrm{pH}=8.0$ biosorption is described by both pseudo-first order and pseudo-second order models. The high correlation coefficients and similarity between $q_{e . m}$ values obtained by the model and $\mathrm{q}_{\mathrm{e}}$ obtained experimentally, indicate better adaptation to the pseudo-first order model for both $\mathrm{pH}$ levels.

The absorbent biochar appears to be a promising low-cost alternative, considering no chemical activation needed.

Acknowledgments: The authors wish to acknowledge the Conselho Nacional de Desenvolvimento Científico e Tecnológico CNPq for scholarship and financial support.

Conflicts of Interest: Declare conflicts of interest or state "The authors declare no conflict of interest."

\section{REFERENCES}

1. Busi, R.; Vila-Aiub, M.M.; Beckie, H.J.; Gaines, T.A.; Goggin, D.E.; Kaundun, S.S. Herbicide-resistant weeds: From research and knowledge to future needs. Evol. Appl. 2013, 6, pp. 1218-1221. https://doi.org/10.1111/eva.12098

2. Rubio, A.J.; Bergamasco, R.; Yamaguchi, N.U. Remoção do herbicida glifosato utilizando carvão ativado impregnado com compostos metálicos de prata e cobre para a melhoria da qualidade da água (Removal of glyphosate using activated carbon coated with silver and copper metal compounds to improve water quality). Rev. Eletrônica em Gestão, Educ. e Tecnol. Ambient. 2016, 20, pp. 450-455. https://doi.org/10.5902/2236117019991

3. Carneiro, R.T.A.; Taketa, T.B.; Gomes Neto, R.J.; Oliveira, J.L. Campos EVR, de Moraes MA, et al. Removal of glyphosate herbicide from water using biopolymer membranes. J. Environ. Manage. 2015,151, pp. 353-360. https://doi.org/10.1016/j.jenvman.2015.01.005 
4. Annett, R.; Habibi, H.R.; Hontela, A. Impact of glyphosate and glyphosate-based herbicides on the freshwater environment. J. Appl. Toxicol. 2014, 34, pp. 458 - 479. https://doi.org/10.1002/jat.2997

5. Martini, L.F.D; Caldas, S.S.; Bolzan, C.M.; Bundt, A.D.C; Primel, E.G.; Avila, L.A. de. Risco de contaminação das águas de superfície e subterrâneas por agrotóxicos recomendados para a cultura do arroz irrigado (Study of the risk of contamination of surface and groundwater by agrochemicals used for irrigation of rice cultures). Cienc. Rural. 2012, 42 (10), pp. 1715-1721. https://doi.org/10.1590/S0103-84782012001000001

6. Bai, S.; Ogbourne, S. Glyphosate: environmental contamination, toxicity and potential risks to human health via food contamination. Environ. Sci. Pollut. Res. 2016, 23, pp.18988-19001. https://doi.org/10.1007/s11356-016-7425-3

7. Ronco, A.E.; Marino, D.J.G.; Abelando, M.; Almada, P.; Apartin, C.D. Water quality of the main tributaries of the Paraná Basin: glyphosate and AMPA in surface water and bottom sediments. Environ. Monit. Assess. 2016, 188.(8), pp.1 - 13 https://doi.org/10.1007/s10661-016-5467-0

8. Webster, T.M.U.; Santos, E.M. Global transcriptomic profiling demonstrates induction of oxidative stress and of compensatory cellular stress responses in brown trout exposed to glyphosate and Roundup. BMC Genomics. 2015, 16, pp. 1-15. https://doi.org/10.1186/s12864-015-1254-5

9. INCA, National Cancer Institute. Standpoint of the National Cancer Institute Jose Alencar da Silva on pesticides. Agronomy Science Academy of Pernambuco, 2015, 11/12, pp. 31-34. http://www.journals.ufrpe.br/index.php/apca/article/viewFile/1090/886 (accessed 18 January 2017).

10. Herath, I.; Kumarathilaka, P.; Al-Wabel, M.I.; Abduljabbar, A.; Ahmad, M.; Usman, A.R.A. et al. Mechanistic modeling of glyphosate interaction with rice husk derived engineered biochar. Microporous Mesoporous Mater. 2016, 225, pp. 280-288. https://doi.org/10.1016/j.micromeso.2016.01.017

11. Campos, W.K.S.; Buarque, F.S.; Macêdo Júnior, R.O.; Silva, D.P.; Ruzene, D.S. Estudo sobre as principais tecnologias para tratamento da água produzida (Study on the main technologies for the treatment of water). Cad. Grad. - Ciências Exatas e Tecnol. 2012, 1, pp.141-152. https://doi.org/2316-3135

12. Nourouzi, M.M.; Chuah, T.G.; Choong, T.S.Y. Adsorption of glyphosate onto activated carbon derived from waste newspaper. Desalin. Water Treat. 2010, 24, pp. 321-326. https://doi.org/10.5004/dwt.2010.1461

13. Dai, L.; Ren, J.; Tao, L.; Li, H.; Hao, J. Effect of sludge biochars obtained at different pyrolysis temperatures on the adsorption of $\mathrm{Cd}(\mathrm{II})$ by loess in Northwestern China. Polish J. Environ. Stud. 2017, 26, pp. 1485-1492. https://doi.org/10.15244/pjoes/69577

14. Rosa, M.F.; Souza Filho, M.S.M.; Figueiredo, M.C.B.; Morais, J.P.S.; Santaella, S.T.; Leitão, R.C. Agroindustry wastes appreciation. In. II International Symposium on Agricultural and Agroindustry wastes management - II SIGERA. Foz do Iguaçu, PR. 2011, 1, pp. 98-105.

15. Ernani, P.; Carvalho, R. Technical Commun 230 - Pequizeiro Caryocar brasiliense. Embrapa, Colombo, PR. 2009, 1-10. https://doi.org/1517-5030

16. Siqueira, B.S.; Alves, L.D.; Vasconcelos, P.N.; Damiani, C.; Soares Júnior, M.S. Pectina extraída de casca de pequi e aplicação em geleia light de manga (Pectin extraction from pequi 
husk and its application in mango light jelly). Rev. Bras. Frutic. 2012, 34, pp. 560-567. https://doi.org/10.1590/S0100-29452012000200030

17. Patias, S.G.O.; Sávio, J.; Costelli, M.C.; da Silva, A.; Cancelier, A.; Lopes, T.J. Obtenção de carvão adsorvente oriundo da casca de pequi (Caryocar brasiliense) e sua aplicação no tratamento de efluentes da indústria têxtil através do processo de adsorção (Obtaining adsorbent char from pequi husk (Caryocar brasiliense) and its application in the treatment of effluents from the textile industry through the adsorption process). Rev. Eletrônica em Gestão, Educ. e Tecnol. Ambient. 2015, 19, pp. 1482-1492.

18. Vu, T.M.; Trinh, V.T.; Doan, D.P.; Van, H.T.; Nguyen, T.V.; Vigneswaran, S. et al. Removing ammonium from water using modified corncob-biochar. Sci. Total Environ. 2017, 579, pp. 612-619. https://doi.org/10.1016/j.scitotenv.2016.11.050

19. Araujo, A.L.P.; Silva, M.C.C.; Gimenes, M.L.; Barros, M.A.S.D. Estudo termodinâmico da adsorção de zinco em argila bentonita bofe calcinada. Sci. plena. 2009, 5, pp.1-6. https://doi.org/10.1590/S0100-40422009000600024

20. Castro, K.C.; Cossolin, A.S.; Reis, H.C.O. dos; Morais, E.B. de; Biosorption of anionic textile dyes from aqueous solution by yeast slurry from brewery., Braz. Arch. Biol. Technol., 2017, 60, pp. $1-13$.

21. Tran, H.N.; You, S.J.; Hosseini-Bandegharaei, A.; Chao, H.P. Mistakes and inconsistencies regarding adsorption of contaminants from aqueous solutions: A critical review. Water Res. 2017, 120, pp. 88-116. https://doi.org/10.1016/j.watres.2017.04.014

22. Vithanage, M.; Mayakaduwa, S.S.; Herath, I.; Ok, Y.S.; Mohan, D. Kinetics, thermodynamics and mechanistic studies of carbofuran removal using biochars from tea waste and rice husks. Chemosphere. 2016, 150, pp. 781-789. https://doi.org/10.1016/j.chemosphere. 2015.11.002

23. Ho, Y.S.; Wang, C.C. Sorption equilibrium of mercury onto ground-up tree fern. J. Hazard. Mater. 2008, 156, pp. 398-404. https://doi.org/10.1016/j.jhazmat.2007.12.030

24. Tzaskos, D.F.; Marcovicz, C.; Dias, N.M.P.; Rosso, N.D. Development of sampling for quantification of glyphosate in natural waters. Ciência e Agrotecnologia. 2012, 36, pp. 399-405. https://doi.org/10.1590/S1413-70542012000400003

25. Bhaskara, B.L.; Nagaraja, P. Direct Sensitive Spectrophotometric Determination of Glyphosate by Using Ninhydrin as a Chromogenic Reagent in Formulations and Environmental Water Samples. Helvetica Chimica Acta, 2006, 89, pp. 2686 - 2693.

26. Mimura, A.M.S.; Vieira, T.V.A.; Martelli, P.B.; Gorgulho, H.F. Aplicação da casca de arroz na adsorção dos íons $\mathrm{Cu}^{2+}, \mathrm{Al}^{3+}, \mathrm{Ni}^{2+} \mathrm{e} \mathrm{Zn}^{2+}$ (Application of rice husk in the adsorption of $\mathrm{Cu}^{2+}, \mathrm{Al}^{3+}$, $\mathrm{Ni}^{2+}$ and $\mathrm{Zn}^{2+}$ ). Quim. Nova. 2010, $33 \quad$ (6), pp.1279-1284. https://doi.org/10.1590/S0100-40422010000600012

27. Amorim, D.J.; Rezende, H.C.; Oliveira, É.L.; Almeida, I.L.S.; Coelho, N.M.M.; Matos, T.N. et al. Characterization of pequi (Caryocar brasiliense) shells and evaluation of their potential for the adsorption of Pbll ions in aqueous systems. J. Braz. Chem. Soc. 2016, 27, pp. 616-623. https://doi.org/http://dx.doi.org/10.5935/0103-5053.20150304

28. Souza, R.S.; Carvalho, S.M.L.; Garcia Júnior, M.R.L.; Sena, R.S.F. Adsorção de cromo (VI) por carvão ativado granular de soluções diluídas utilizando um sistema batelada sob pH controlado (Adsorption of chromium ( $\mathrm{VI}$ ) by granular activated carbon from diluted solutions using a batch 
Biochar from pequi for the removal of glyphosate

system under controlled pH). Acta Amaz. 2009, 39, pp. 661-668. https://doi.org/10.1590/S0044-59672009000300022

29. Róz, A.L. da; Ricardo, J.F.C.; Nakashima, G.T.; Santos, L.R.O.; Yamaji, F.M. Maximização do teor de carbono fixo em biocarvão aplicado ao sequestro de carbono (Maximization of carbon content in biochar to carbon sequestration). Rev. Bras. Eng. Agrícola e Ambient. 2015, 19, pp. 810-814. https://doi.org/10.1590/1807-1929/agriambi.v19n8p810-814

30. Chowdhury, Z.Z.; Karim, Md. Z.; Ashraf, M. A.; Khalid, K. Influence of Carbonization Temperature on Physicochemical Properties of Biochar derived from Slow Pyrolysis of Durian Wood (Durio zibethinus) Sawdust. BioResources, 2016, 11(2), pp. 3356 - 3372.

31. Novak, J.M.; Lima, I.; Xing, B.; Gaskin, J.W.; Steiner, C.; Das, K.C. Characterization of designer biochar produced at different temperatures and their effects on a loamy sand. Ann. Environ. Sci. 2009, 3, pp. 195-206.

32. Smith, J.L.; Collins, H.P.; Bailey, V.L. The effect of young biochar on soil respiration. Soil Biol. Biochem. 2010, 42, pp. 2345-2347. https://doi.org/10.1016/j.soilbio.2010.09.013

33. Cho, S.Y.; Park, S.S.; Kim, S.J.; Kim, T.Y. Adsorption and desorption characteristics of 2-methyl-4-chlorophenoxyacetic acid onto activated carbon. Korean J. Chem. Eng. 2006, 23, pp. 638-644. https://doi.org/10.1007/BF02706807

34. Mayakaduwa, S.S.; Kumarathilaka, P.; Herath, I.; Ahmad, M.; Al-Wabel, M.; Ok, Y.S. Equilibrium and kinetic mechanisms of woody biochar on aqueous glyphosate removal. Chemosphere. 2016, 144, pp. 2516-2521. https://doi.org/10.1016/j.chemosphere.2015.07.080

35. Essandoh, M.; Kunwar, B.; Pittman, C.U.; Mohan, D.; Mlsna, T. Sorptive removal of salicylic acid and ibuprofen from aqueous solutions using pine wood fast pyrolysis biochar. Chem. Eng. J. 2015, 265, pp. 219-227. https://doi.org/10.1016/j.cej.2014.12.006

36. Tran, H.N.; You, S.J.; Chao, H.P. Effect of pyrolysis temperatures and times on the adsorption of cadmium onto orange peel derived biochar. Waste Manag. Res. 2016, 34, pp.129-138. https://doi.org/10.1177/0734242X15615698

37. Xu, R. K.; Xiao, S. C.; Yuan, J. H.; Zhao, A. Z. Adsorption of methyl violet from aqueous solutions by the biochars derived from crop residues. Bioresour. Technol. 2011, 102, pp.10293-10298. https://doi.org/10.1016/j.biortech.2011.08.089

38. Wang, Z.; Shen, D.; Shen, F.; Li, T. Phosphate adsorption on lanthanum loaded biochar. Chemosphere. 2016, 150, pp. 1-7. https://doi.org/10.1016/j.chemosphere.2016.02.004

39. Vithanage, M.; Rajapaksha, A.U.; Ahmad, M.; Uchimiya, M.; Dou, X.; Alessi, D.S. Mechanisms of antimony adsorption onto soybean stover-derived biochar in aqueous solutions. J. Environ. Manage. 2015, 151, pp. 443-449. https://doi.org/10.1016/j.jenvman.2014.11.005

40. Iqbal, M.; Saeed, A.; Zafar, S.I. FTIR spectrophotometry, kinetics and adsorption isotherms modeling, ion exchange, and EDX analysis for understanding the mechanism of $\mathrm{Cd}^{2+}$ and $\mathrm{Pb}^{2+}$ removal by mango peel waste. J. Hazard. Mater. 2009, 164, pp. 161-171. https://doi.org/10.1016/j.jhazmat.2008.07.141

41. Sun, L.; Chen, D.; Wan, S.; Yu, Z. Performance, kinetics, and equilibrium of methylene blue adsorption on biochar derived from eucalyptus saw dust modified with citric, tartaric, and acetic acids. $\quad$ Bioresour. Technol. 2015, 198, 300-308. https://doi.org/10.1016/j.biortech.2015.09.026 
42. Sun, L.; Wan, S.; Luo, W. Biochars prepared from anaerobic digestion residue, palm bark, and eucalyptus for adsorption of cationic methylene blue dye: Characterization, equilibrium, and kinetic studies. Bioresour. Technol. 2013, 140, pp. 406-413. https://doi.org/10.1016/j.biortech.2013.04.116

43. Gao, D.W.; Hu, Q.; Pan, H.; Jiang, J.; Wang, P. High-capacity adsorption of aniline using surface modification of lignocellulose-biomass jute fibers. Bioresour. Technol. 2015, 193, pp. 507-512. https://doi.org/10.1016/j.biortech.2015.06.138

44. Tush, D.; Meyer, M.T. Polyoxyethylene Tallow Amine, a Glyphosate Formulation Adjuvant: Soil Adsorption Characteristics, Degradation Profile, and Occurrence on Selected Soils from Agricultural Fields in lowa, Illinois, Indiana, Kansas, Mississippi, and Missouri. Environ. Sci. Technol. 2016, 50, pp. 5781-5789. https://doi.org/10.1021/acs.est.6b00965 